\title{
Sol-Gel Electrochromic Device
}

\author{
Code: F8
}

\section{M.A. MACÊDO AND M.A. AEGERTER}

Institute of Physics and Chemistry of São Carlos, University of São Paulo, Cx. Postal 369, 13560-970 São Carlos (SP), Brazil

\begin{abstract}
All solid state electrochromic devices have potential applications in architectural and automotive fields to regulate the transmission and reflection of radiant energy. We present the optical and electrochemical characteristics of two solid state windows having the configuration glass/ITO/TiO $-\mathrm{CeO}_{2} / \mathrm{TiO}_{2} / \mathrm{TiO}_{2}-\mathrm{CeO}_{2} / \mathrm{TTO} /$ glass and glass/ITO $/ \mathrm{WO}_{3} / \mathrm{TiO}_{2} / \mathrm{TiO}_{2}-\mathrm{CeO}_{2} / \mathrm{TTO} /$ glass where the three internal layers have been prepared by sol gel methods. The preparation of the individual sols and some physical properties of the different sol gel coatings are reported.
\end{abstract}

Keywords: electrochromism, electrochemistry, $\mathrm{WO}_{3} / \mathrm{TiO}_{2}$ layers, films: $\mathrm{TiO}_{2}$

\section{Introduction}

The development of all solid state electrochromic devices such as smart windows, displays, automotive rearview mirrors, etc, presents a considerable technological and commercial interest [1]. These devices consist of multiple layers usually sandwiched between two glass layers. A typical device working in transmission has the configuration glass/transparent electron conductor/anode/ionic conductor/cathode/transparent electron conductor/glass. The outermost layers on each side are transparent electron conductors (TC) and are required to set up a distributed electric field. The adjacent layers are the electrochromic layer (EC) and the counter electrode which plays the role of the ion storage layer (IS) for $\mathrm{H}^{+}$or $\mathrm{Li}^{+}$ions. The central layer is an ion conductor (IC). The three inside layers essentially comprise an electro-optically active battery and therefore the (EC) and (IS) layers are mixed electron-ion conductor. When a small current is passed through the cell the ions stored in the (IS) layer diffuse toward the electrochromic layer which has the property to change its spectral transmittance continuously (usually over a wide spectral range) altering the overall optical transmission of the device. The original optical bleached state is obtained by reversing the applied voltage. Such devices have a time response which varies from seconds to minutes and can usually maintain their optical properties (bleached or colored state) when the power is turned off (memory effect).

Various inorganic materials and processes have been proposed for each specific layer (see $[1,2]$ for recent reviews). Nowadays indium tin oxide (ITO) is the preferred $\mathrm{TC}$ material. $\mathrm{WO}_{3}, \mathrm{MoO}_{3}, \mathrm{Nb}_{2} \mathrm{O}_{5}$ are typical cathodic EC materials while $\mathrm{IrO}_{2}, \mathrm{NiO}, \mathrm{Ni}(\mathrm{OH})_{2}$ are anodic EC materials and $\mathrm{Rh}_{2} \mathrm{O}_{3}$ and $\mathrm{V}_{2} \mathrm{O}_{5}$ were found to color in both states. $\mathrm{V}_{2} \mathrm{O}_{5}, \mathrm{Ir}_{2} \mathrm{O}_{3}, \mathrm{CeO}_{2}$ and $\mathrm{TiO}_{2}-\mathrm{CeO}_{2}$ have been proposed for counter electrode, the last material showing better $\mathrm{Li}^{+}$insertion kinetics. Materials such as hydrated $\mathrm{Ta}_{2} \mathrm{O}_{5}, \mathrm{ZrO}_{2}, \mathrm{SiO}_{2}$, $\mathrm{TiO}_{2}$ can be used as $\mathrm{H}^{+}$conductor while $\mathrm{Li}_{3} \mathrm{~N}, \mathrm{LiAlF}_{4}$, $\mathrm{LiNbO}_{3}, \mathrm{LiTiO}_{3}$ and $\mathrm{LiAlSiO}_{4}$ have been proposed for $\mathrm{Li}^{+}$. However none of them exhibits the high ionic conductivity as obtained with polymeric or liquid electrolytes which are still the preferred materials used in commercial or prototype devices.

Most of these materials have been already processed by sol-gel methods and a recent review can be found in [2]. Their specific functions to be used as EC or IS layers in electrochromic devices has been demonstrated for $\mathrm{WO}_{3}, \mathrm{WO}_{3}-\mathrm{TiO}_{2}, \mathrm{WO}_{3}-\mathrm{MoO}_{3}, \mathrm{Nb}_{2} \mathrm{O}_{5}$, $\mathrm{TiO}_{2}-\mathrm{CeO}_{2}, \mathrm{~V}_{2} \mathrm{O}_{5}, \mathrm{NbVO}_{5}, \mathrm{TaVO}_{5}, \mathrm{MoO}_{3}$, oxides of $\mathrm{Ir}, \mathrm{Ni}, \mathrm{Cr}, \mathrm{Y}, \mathrm{Cu}, \mathrm{Co}, \mathrm{Fe}, \mathrm{Mn}, \mathrm{Ni}-\mathrm{Co}, \mathrm{TiO}_{2}$ and $\mathrm{CeO}_{2}$. Very few works have been reported for transparent IC layers where we can mention $\mathrm{TiO}_{2}$, Ormosils and for transparent TC layers ITO.

In this paper we present the preparation of the sols used to obtain $\mathrm{EC}\left(\mathrm{WO}_{3}\right), \mathrm{IC}\left(\mathrm{TiO}_{2}\right)$ and $\mathrm{IS}\left(\mathrm{TiO}_{2}-\right.$ 
$\mathrm{CeO}_{2}$ ) layers as well as optical and electrochemical solid properties of two all solid state smart windows built with these layers having the configuration glass/ITO/TiO ${ }_{2}-\mathrm{CeO}_{2} / \mathrm{TiO}_{2}-\mathrm{CeO}_{2} / \mathrm{ITO} /$ glass and glass $/ \mathrm{ITO} / \mathrm{WO}_{3} / \mathrm{TiO}_{2} / \mathrm{TiO}_{2}-\mathrm{CeO}_{2} / \mathrm{TTO} /$ glass.

\section{Experimental and Procedure}

The different layers of the sol-gel electrochromic cells have been obtained or prepared as following:

a) The transparent electric conductors (TC) were all ITO layers supplied by Donnely (FW 5005, $\rho=$ $2.6 \cdot 10^{-4} \Omega \mathrm{cm}$ ) or Asahi Glass (plasma assisted evaporation $\rho=3.5 \cdot 10^{-4} \Omega \mathrm{cm}$ ) noted $\mathrm{D}$ and $\mathrm{Ag}$ respectively. Sol-gel processing of these coatings is feasible [3] [4] [5] but the electron conductivity is typically one order of magnitude smaller.

b) The ion storage coating (IS) or counter electrode consists of a $\mathrm{TiO}_{2}-\mathrm{CeO}_{2}$ layer deposited by dipcoating technique using a sol prepared from a mixture of $\mathrm{Ce}\left(\mathrm{NH}_{4}\right)_{2}\left(\mathrm{NO}_{3}\right)_{6}$ dissolved in ethanol, isopropanol or glycol ether to which was added tetraisopropyl orthotitanate with atomic ratio $\mathrm{Ce}: \mathrm{Ti}$ up to $1: 1$ according to a method already described [6] [7] [8] [9]. These sols are stable up to 3 months when kept at $5^{\circ} \mathrm{C}[10]$. The layers deposited on the ITO coated glass at a $20 \mathrm{~cm} / \mathrm{min}$ withdrawal speed have a thickness of about $70 \mathrm{~nm}$. After drying at room temperature for 15 minutes they have been partially densified by a heat treatment in air at $500^{\circ} \mathrm{C}$. The amount of charge which can be inserted in such layers depends on the time and temperature of the heat treatment and the thickness of the layer. As shown below the highest charge density has been obtained with $\sim 250 \mathrm{~nm}$ thick layer obtained by repeating the deposition process 3 to 4 times. After each deposition the layers have been fired at $500^{\circ} \mathrm{C}$ during 5 mintues. After the last coating the whole stack has been heat treated at the same temperature during 120 minutes.

c) The $\mathrm{WO}_{3}$ electrochromic coating was deposited by dip-coating on ITO coated glass from a colloidal solution obtained by dissolving tungsten tetrachloride oxide $\left(\mathrm{WOCl}_{4}\right)$ in isopropanol $(0.1 \mathrm{M})$ and processed as previously described by Judeinstein et al [11] [12]. Each layer was $50 \mathrm{~nm}$ thick and the dipcoating process, done in $30 \% \mathrm{RH}$ at a rate of 20 $\mathrm{cm} / \mathrm{min}$, was repeated 5 times in order to obtain a final layer $200 \mathrm{~nm}$ thick. The densification was performed at $120^{\circ} \mathrm{C}$ during $24 \mathrm{~h}$. The layers are amorphous.

d) $\mathrm{The}_{\mathrm{TiO}}$ sol gel protonic electrolyte was prepared according to a method proposed by Judeinstein et al [11] [12]. $\mathrm{Ti}\left(\mathrm{OBu}^{n}\right)_{4}$ was however substituted by Ti(IV) $i$-propoxide. The alkoxide was first mixed with glacial acetic acid in a molar ratio 1:2 and then glycerol (G) or ethylene glycol (EG) was added in a molar ratio $\mathrm{G}$ or $\mathrm{EG} / \mathrm{Ti}=20$. According to the literature the reacted mixture gives glycolate derivatives where the organic groups may behave as bridging ligands between Ti metal atoms. No water was added. The resulting material is a viscous organic-inorganic liquid. For these concentrations gels are obtained after 15 and 10 days respectively. The same procedure used with a mixture of acetylacetone and $\mathrm{Ti}$ alkoxide (ratio 2:1) leads also to a slightly viscous organic-inorganic liquid whose stability is improved as no gelification has been observed even in presence of water after more than 1 month.

The final assembly of the cell was done by depositing a thin layer of the viscous electrolyte on the IS/ITO/glass stack. The other side of the window was then firmly pressed against it and the whole cell was finally sealed with Torr Seal glue.

\section{Characterization of the Coatings, Windows and Discussion}

The $\mathrm{TiO}_{2}-\mathrm{CeO}_{2}$ coating used as ion storage is transparent, slightly yellow and consists of small $\mathrm{CeO}_{2}$ crystallites embedded in an amorphous $\mathrm{TiO}_{2}$ matrix [6-10] [13]. Optically a broad unstructured absorption band ( $\mathrm{OD} \equiv 0.25)$ is observed below $\lambda=400$ $\mathrm{nm}$ peaking at $240 \mathrm{~nm}$; the coating remains totally transparent in the visible-near infrared region during the cycling process. It allows a fully reversible $\mathrm{H}^{+}$or $\mathrm{Li}^{+}$insertion or extraction controlled by solid state diffusion. The amount of charge which can be inserted into the layer measured by integrating voltammetry curves increases almost linearly with the thickness of the layer up to $\sim 250 \mathrm{~nm}$ (corresponding to 3 to 4 layers) and then slightly diminishes. For $\mathrm{Li}^{+}$for example using a cell glass/ITO/TiO ${ }_{2}$ $\mathrm{CeO}_{2}$ /propylene carbonate (PC) $-0.1 \mathrm{M} \mathrm{LiClO} / \mathrm{Pt}$ with reference $\mathrm{Ag} / \mathrm{Ag}^{+} / \mathrm{PC}-0.2 \mathrm{M}\left(\mathrm{Et}_{4} \mathrm{~N}\right) \mathrm{ClO}_{4}$ and voltammetry parameters $50 \mathrm{mV} / \mathrm{s},+1,6 \mathrm{~V}$ to -1 , 


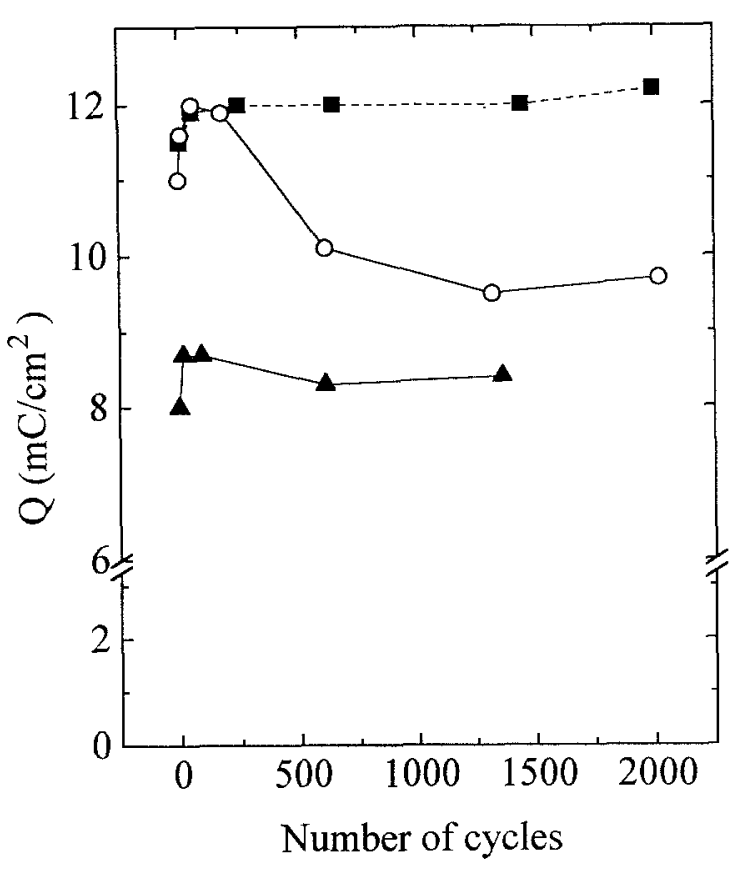

Fig. 1. Total $\mathrm{H}^{+}$and $\mathrm{Li}^{+}$charge inserted or extracted in a $210 \mathrm{~nm}$ thick sol gel $\mathrm{TiO}_{2}-\mathrm{CeO}_{2}$ layer as a function of the number of cycles showing a stable long term behavior. The plain curves refer to coating prepared with glycol ether $(\boldsymbol{\Delta})$, or isopropanol (o) and tested with $\mathrm{Li}^{+}$. The dashed curve is obtained with isopropanol $(\square)$ and tested with $\mathrm{H}^{+}$. Voltammetry parameters for $\mathrm{H}^{+}$; cell glass/ITO/TiO $\mathrm{CeO}_{2} / \mathrm{TiO}_{2} / \mathrm{gel} / \mathrm{Pt}$ with reference $\mathrm{SCE}$; rate $50 \mathrm{~m} \mathrm{~V} / \mathrm{s}$; potentials: $+3.4 \mathrm{~V}$ to $-2.0 \mathrm{~V}$. Voltammetry parameters for $\mathrm{Li}^{+}$: see text.

$6 \mathrm{~V}$, the increase is typically $50 \mu \mathrm{C} / \mathrm{cm}^{2}$ up to $\sim 11$ $\mathrm{mC} / \mathrm{cm}^{2}$. The new heat treatment protocol has definitively improved the charge values, reflecting a corresponding increase of the number of sites for $\mathrm{Li}^{+}$insertion. The slight decrease observed for thicker layer is not completely understood; analysis of voltammetry curves shows a continuous shift of the insertion and extraction peak toward higher or lower potential respectively suggesting a gradual increase of the electric resistance of the coating causing a drop of the effective potential at the electrolyte/electrode interface. Figure 1 shows typical long term behavior of the total $\mathrm{H}^{+}$ and $\mathrm{Li}^{+}$charge inserted (or extracted) in a $\mathrm{TiO}_{2}-\mathrm{CeO}_{2}$ three layers coating. After an initial rise followed by a slight decrease, the values of the charge stabilizes typically between 8.5 and $12 \mathrm{mC} / \mathrm{cm}^{2}$.

The long term response of the IC/IS/ITO glass stack has been tested for protonic conduction by submitting all solid state symmetric cells having the configuration glass/ITO/TiO ${ }_{2}-\mathrm{CeO}_{2} / \mathrm{TiO}_{2} / \mathrm{TiO}_{2}-\mathrm{CeO}_{2} / \mathrm{ITO} /$ glass to extended potentiostatic and/or voltammetry cycles. The protonic electolyte has been prepared with a ra-

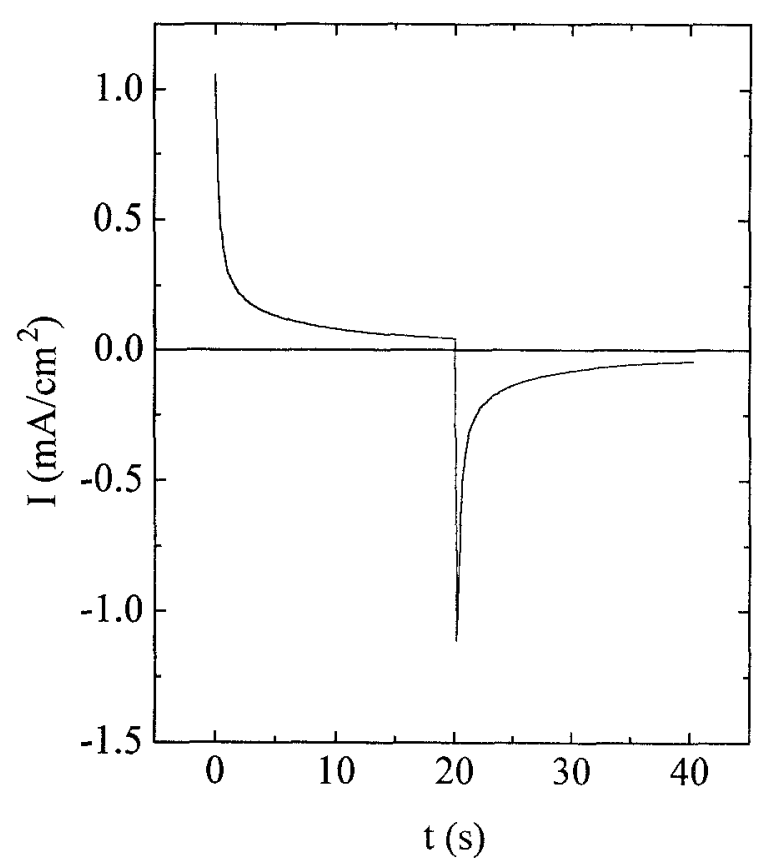

Fig. 2. Time response of a glass/ITO/TiO ${ }_{2}-\mathrm{CeO}_{2} / \mathrm{TiO}_{2}-$ $\mathrm{CeO}_{2} / \mathrm{ITO} /$ glass to square wave voltage of $\pm 0.8 \mathrm{~V}$, period $40 \mathrm{~s}$. The protonic IC layer was prepared with a ratio acetic acid/Ti $=4$. No extra charge has been inserted.

tio acetic acid/Ti varying between 4 and 16 . Such cells do not exhibit any coloration during the cycling. The voltammetry curves were found practically symmetric and no degradation has been observed electrochemically or by visual inspection of the cell up to 30000 cycles or when kept on the shelf in open circuit for several weeks (test are still in progress). The time response of the current density flowing through the cell to square wave voltage of $\pm 0.8 \mathrm{~V}$ applied with a period of $40 \mathrm{~s}$ is shown in Figure 2 for the $29340^{\text {th }}$ cycle. A fast switching time $(\sim 2,5 \mathrm{~s})$ is observed for both the insertion or extraction process showing that the sol gel stack $\mathrm{TiO}_{2} / \mathrm{TiO}_{2}-\mathrm{CeO}_{2} / \mathrm{TO} /$ glass performs perfectly well for the proposed purpose. It is worth while to note that the cell configuration employed in this test is of no use for optical devices but other applications such as all sol gel thin solid state battery can be foreseen.

Similar measurements (not reported here) are in progress in order to test the symmetric configuration glass/ITO/ $/ \mathrm{WO}_{3} / \mathrm{TiO}_{2} / \mathrm{WO}_{3} / \mathrm{ITO} /$ glass.

Finally complete $10 \mathrm{~cm}^{2}$ electrochromic windows having the configuration glass/ITO/ $/ \mathrm{WO}_{3} / \mathrm{TiO}_{2} / \mathrm{TiO}_{2}$ $\mathrm{CeO}_{2} / \mathrm{ITO} /$ glass have been built with the three internal active layers prepared by sol gel methods. Figure 3 shows typical optical transmission measured in 


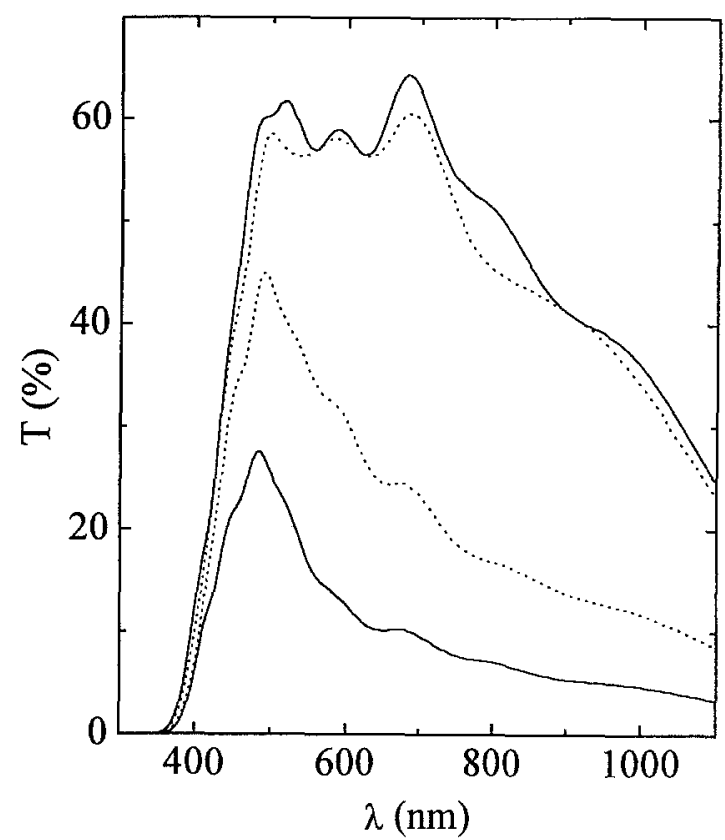

Fig. 3. Visible-near infrared transmission of a cell glass/ ITO $/ \mathrm{WO}_{3} / \mathrm{TiO}_{2}-\mathrm{CeO}_{2} / \mathrm{ITO} /$ glass in the bleached and colored state; $-1^{\text {st }}$ cycle, $--360^{\text {th }}$ cycle.

the visible-near IR region in the bleached and colored states. The results obtained with the $1^{\text {st }} \mathrm{cy}$ cle are totally comparable with those obtained with windows built with layers prepared by other coating methods [14] [15]. Figure 4 shows the time response of the current density flowing through the device to square wave voltage held at $\pm 1.5 \mathrm{~V}$ limits for $60 \mathrm{~s}$. The coloring and bleaching kinetics are fast $(<10 \mathrm{~s})$. The bleaching response reflects a curvature change around $20 \mathrm{~s}$; such a behavior was already observed in a window. . $/ \mathrm{Li}_{x} \mathrm{WO}_{3} /$ polymer electrolyte $/ \mathrm{TiO}_{2}-$ $\mathrm{CeO}_{2} / \ldots$. [13] and attributed to a decrease of the ion diffusion coefficient during its insertion into the IS electrode when its concentration reaches a certain value.

The main problem which remains to be solved is the lifetime of the present device. Figures 3 and 4 show also the results obtained at the $360^{\text {th }}$ cycle. They clearly indicate a degradation. Visual inspection of the devices shows a lack of adherence between two layers as seen by the presence of interference patterns. The origin of the phenomenon is not known yet. As no degradation has been reported in the first window (up to 30000 cycles) it is highly probable that the problem lies at the $\mathrm{WO}_{3} / \mathrm{TiO}_{2}$ interface. Chemical reactions between the materials may provoke stresses or evolve gases at the interface forcing the layer to separate. Coating of the $\mathrm{WO}_{3}$ layer by a thin layer of

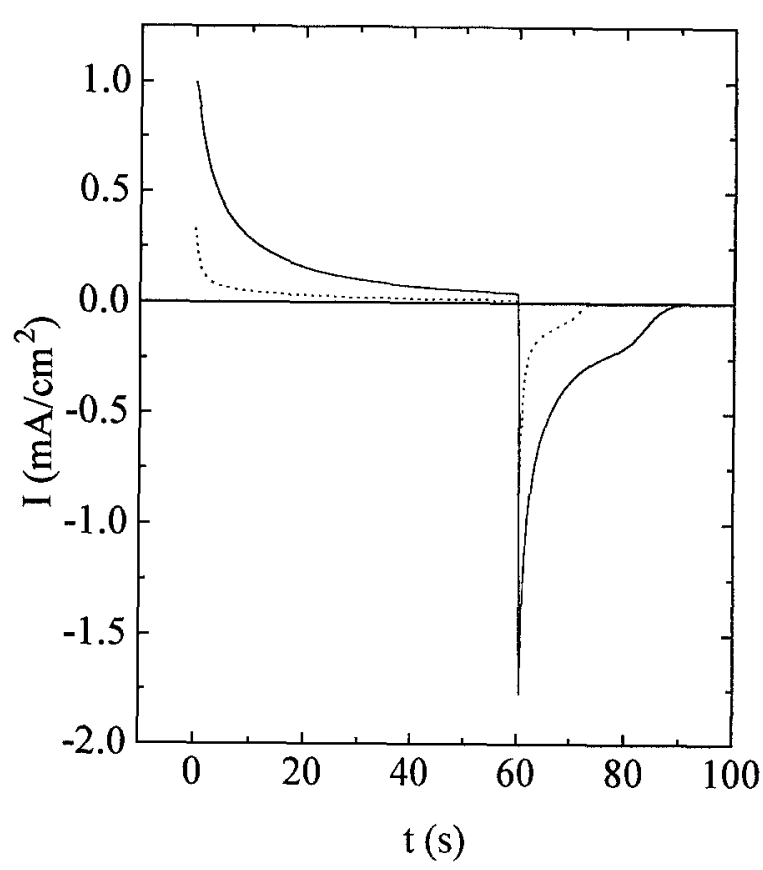

Fig. 4. Current variation to square wave voltage $( \pm 1.5 \mathrm{~V}$, period 60 s) of the cell of Figure $3 ;-1^{\text {st }}$ cycle, $--360^{\text {th }}$ cycle.

$\mathrm{Ta}_{2} \mathrm{O}_{5}$ as proposed by Cogan et al [15] as an effective protection from the degradation against reaction of this material with a poly AMPs electrolyte may be useful. However as Judeinstein et al $[11,12]$ claimed a lifetime longer than 40000 cycles for a symmetric always colored cell $\mathrm{SnO}_{2} / \mathrm{WO}_{3} / \mathrm{TiO}_{2} / \mathrm{WO}_{3} / \mathrm{SnO}_{2}$ whose active layers have been realized with the same sol gel methods, we believed that the problem lies in the adequate composition of the electrolyte. However failure due to hydrogen embrittlement or generation is not discarded [16].

\section{Conclusion}

We have presented two all solid electrochromic windows whose three internal active layers have been realized by sol gel methods and using protons as ionic carriers. The first one had the symmetric configuration glass/ITO/TiO ${ }_{2}-\mathrm{CeO}_{2} / \mathrm{TiO}_{2} / \mathrm{TiO}_{2}-$ $\mathrm{CeO}_{2} / \mathrm{ITO} /$ glass and does not show any visible coloration during the cycling since $\mathrm{TiO}_{2}-\mathrm{CeO}_{2}$ does not color. This device can be useful for other application such as solid state battery. This configuration was used to test the lifetime of the $\mathrm{TiO}_{2} / \mathrm{TiO}_{2}-\mathrm{CeO}_{2} / \mathrm{ITO} /$ glass side of the optical device. This part performed perfectly up to 30000 cycles with no apparent opti- 
cal and electrochromic degradation (longer time test still in progress). The non-symmetric optical window having the configuration glass/ITO/ $/ \mathrm{WO}_{3} / \mathrm{TiO}_{2} / \mathrm{TiO}_{2}-$ $\mathrm{CeO}_{2} / \mathrm{TTO} /$ glass shows optical transmission change between the colored and bleached state and kinetics totally comparable to similar devices whose layers have been processed by other techniques. The lifetime of our sol-gel device is however shorter. This is due to a lack of adherence betwen the EC and IC elecrodes. It is suggested that this failure can be eliminated by choosing an adequate composition in the preparation of the $\mathrm{TiO}_{2}$ electrolyte. Nevertheless, if we discard this lifetime problem, we have shown that it is possible now to obtain complete sol-gel electrochromic devices showing comparable optical properties as those obtained using other methods of preparation.

\section{Acknowledgment}

This research was financed by FAPESP, FINEP and the program RHAE/New Materials (Brazil).

\section{References}

1. Lampert, C.M. and Grandqvist, C.G., Large-area chromogenics: materials and devices for transmittance control, SPIE, Bellingham, (1990) IS4.
2. Agrawal, M., Cronin, J.P., and Zang, R., Sol gel optics II, SPIE (1992), 1758, p. 330.

3. Ogiwara, S. and Kinugawa, K., Yogyo-Kyokai-Shi (in Japanese) 90, 157 (1982).

4. Gonzalez-Oliver, G.J.R. and Kato, I., J. Non-Cryst. Solids 82, 400 (1986).

5. Dislich, H., J. Non-Cryst. Solids 57, 371 (1983).

6. Tonazzi, J.C.L., Valla, B., Macedo, M.A., Baudry, P., and Aegerter, M.A., SPIE (1990), 1328, p. 375.

7. Baudry, P., Aegerter, M.A., Derro, D., and Valla, B., J. Electrochem. Soc. 138, 460 (1991).

8. Valla, B., Tonazzi, J.C L., Macedo, M.A., Dall'Antonia, L.H., Aegerter, M.A., Gomes, M.A.B., and Bulhoes, L.O., SPIE (1991), 1536

9. Aegerter, M.A., Patent pending No. WO $91 / 02282$ (PCT/BR90/00006), (1991).

10. Macedo, M.A., Dall'Antonia, L.H., and Aegerter, M.A., MRS (1992), 276, p. 125.

11. Judeinstein, P., Livage, J., Zarndiansky, A., and Rose, R., Solid State Ionics 28-30, 1722 (1988).

12. Judeinstein, P. and Livage, J., Sol-gel Optics, SPIE (1990), 1328, p. 344.

13. Macedo, M.A., Dall'Antonia, L.H., Valla, B., and Aegerter, M.A., J. Non-Cryst. Solids 147/148, 792 (1992).

14. Goldner, R.B., Seward, G., Wong, K., Haas, T., Foley, G.H., Chapman, R., and Schulz, S., Solar Energy Materials 19, 17 (1988).

15. Cogan, S.F. and Rauch, R.D., Reference 1, 482.

16. Czanderna, M.W. and Lampert, C.M., SERI/TP-255-3637, (1990) 